\title{
Dr. Anna Bayerová: The First Official Female Doctor in Bosnia and Herzegovina
}

\author{
Brigitte Fuchs ${ }^{1}$, Husref Tahirović ${ }^{2}$
}

${ }^{1}$ Department of Cultural and Social Anthropology at the University of Vienna, Vienna, Austria, ${ }^{2}$ Department of Medical Sciences of the Academy of Sciences and Arts of Bosnia and Herzegovina, Sarajevo, Bosnia and Herzegovina

Correspondence:

brigitte.fuchs@univie.ac.at

Tel.: + 436506505150

Fax.: + 431427749533

Received: 1 April 2019

Accepted: 25 April 2019

Key Words: Medical History of AustroHungarian Occupied BH - Treatment of Muslim Women by Female Physicians

- Anna Bayerová - Bayerovás Medical Practice in Tuzla - Bayerovás Political Activities in Sarajevo.
This biographical note details Anna Bayerovás (1853-1924) activities as the first female Austro-Hungarian health officer in 1878 to1918 occupied Bosnia and Herzegovina (BH). Anna Bayerová is known as a heroine of Czech feminism and the 'first Czech female physician', though she only practised in the Czech lands from 1913 to 1916. In 1891, Bayerová was enrolled as the first Austro-Hungarian female health officer and assigned to treat Muslim women in the district of Tuzla, Bosnia. She pursued this mission for the first three months of 1892, had herself transferred to Sarajevo in the summer, and soon thereafter quitted the service. Her biographers point to a series of political and personal motivations to abandon her mission in Bosnia, which, from the viewpoint of Czech feminists, included fulfilling her professional duties in an exemplary way. She spent most of her professional life as a physician in Switzerland and did not request Austrian recognition of her medical degree until 1913. Bayerová died in Prague in 1924. Conclusion. Bayerová, partly for political reasons and partly due to her panic-fuelled fear of catching tuberculosis, quitted her role as the first Austro-Hungarian female health officer in $\mathrm{BH}$ soon after her arrival in 1892.

\section{Introduction}

Anna Bayerová (1853-1924), a heroine of Czech feminism, is known as the 'first Czech female physician'. Several detailed biographies have been dedicated to her memory (1-4), and she appears in contemporaneous Czech (5) and German $(6,7)$ national physicians' listings and international female physicians' encyclopaedias (8). In Switzerland, the German Empire and Austria, her name was once Germanised as 'Anna Bayer'.

Bayerová finished her medical studies in Berne in 1881 and spent most of her active live in Switzerland where she became involved into the anti-alcohol campaigning linked to contemporaneous European movements of temperance and social reform (9). She owed her prominence to her close ties with the Czech women's movement and her lead role in Czech feminists' and Austrian social democrats' campaigns to admit women to academic, particularly medical, educational institutions. These parties felt that female physicians would improve poor women's and children's access to healthcare (10). Bayerová helped to articulate this mission in Ženské Listy, the journal of the Czech women's movement, from the early 1880 s (11). 
When in 1891 Bénjamin de Kállay, Austria-Hungary's Joint Minister of Finance and de-facto governor of the occupied Ottoman province Bosnia and Herzegovina (BH), created a position for an Austro-Hungarian female health officer, Bayerová was considered predestined to pioneer the broader implementation of a feminist concept of public health and women's studies in Austria (12). Austro-Hungarian universities did not admit female students until 1897, but Kállay was convinced that the prioritized modernization of $\mathrm{BH}$ required extraordinary measures, not least of which included employing female physicians to educate the rural (female) population about public health and hygiene (13).

First, Kállay agreed with contemporary international (14) and Czech feminist arguments that the improvement of working class and poor rural women's and children's health depended on a public health system with state-employed female physicians (14). Second, a systematic Austro-Hungarian health census of the Bosnian population had revealed the spread of infectious diseases such as peculiarly (not sexually transmitted) endemic syphilis (frenjak), the eradication of which was considered another AustroHungarian priority regarding the 'occupied territory' (15). Third, the fact that 35 percent of Bosnia's population was Muslim (16) justified the argument that women's healthcare be performed by female physicians to accommodate 'religious modesty' (17). Thus, Kállay avoided any protest from Austro-Hungarian medical bodies, while the Czech women's movement succeeded in placing Anna Bayerová as the first female Austro-Hungarian health officer in $\mathrm{BH}$. However, Bayerová is not sufficiently recognized in the medical historiography of $\mathrm{BH}$ (18-20), so this paper will be the first article written only about Dr. Anna Bayerova published in $\mathrm{BH}$.

This paper aims to present a short biography of Bayerová and her work as the first female doctor in $\mathrm{BH}$, based on the vast Czech literature on her life and activities $(21,22,13)$.

\section{Bayerovás Short Biography}

Bayerová was born into a lower-middle-class family in Melník, a small town 30 kilometres north of Prague, on November 4, 1853. ${ }^{1}$ She attended the first Czech collegiate school for girls, which had been founded by the Czech Women Professionals' Association in Prague (Ženský Výrobní Spolek Český v Praze). The doyenne of the Czech womens's movement and editor in chief of Ženské Listy, Eliška Krásnohorská herself seems to have encouraged Bayerová to realize her 'great dream' of becoming a physician and raised funds for her to attend a Swiss university (23).

In 1874, Bayerová took the general qualification for university entrance exam ( $\mathrm{Ma}$ tura) in Switzerland and enrolled at the University of Zurich. In 1877, she transferred to the University of Berne and earned her medical degree in 1881, one year after her compatriot Bohuslava Kecková (1854-1911) was awarded a degree in Zurich. However, because of Bayerovás involvement in the Czech women's movement, she was the one who would be celebrated in Ženské Listy and the Journal of Czech Physicians as the 'first Czech female physician' in 1881.

In 1882, Bayerová volunteered as an assistant doctor at the Royal Maternity Clinic in Dresden, directed by the renowned German gynaecologist Franz von Winckel (1837-1911), who supported 'women's need of female physicians' ('Aerztinnen für Frauen' in German) (24). Subsequently, Bayerová took over a medical office in Teufen, a village near St. Gallen in Switzerland, which proved to be poorly attended. In 1887, she

${ }^{1}$ Bayerovás earlier biographers gave 1854 as the year of her birth, while more recent international biographies state it as 1852. Following Czech sources, the correct year is 1853 . 
requested and received nationalization in Switzerland in order to establish her own practice in Berne (23).

In 1891, Krásnohorská urged Bayerová to apply for the advertised position of a female physician in Tuzla, a small town in the northeast region of $\mathrm{BH}$. She was accepted by defacto governor Kállay, who summoned her for a confidential conversation in Vienna in December. According to Bayerová, Kállay instructed her personally to educate Bosnian Muslim women about hygiene (21). She was immediately transferred to Sarajevo, where she was sworn into the office of 'provincial female physician' (Landesärztin) (21) in the rank of a captain of the Austro-Hungarian army (Picture 1).

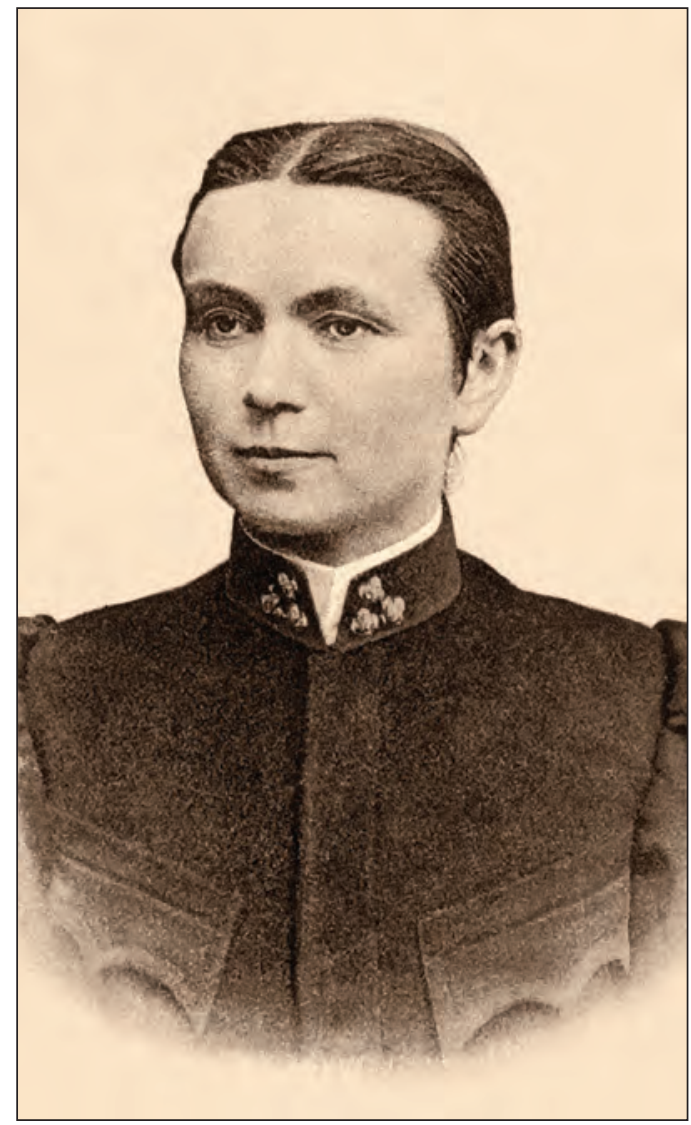

Picture 1. Anna Bayerová (1891) in the uniform of the Austro-Hungarian army while serving as a 'provincial female physician' of Bosnia (Landesärztin in Bosnien). Source: Navrátil M. Almanach Českych Lékařŭ, Praha 1913, s.p. (5).
At that time, living conditions in $\mathrm{BH}$ were very poor. The level of education, especially among the female Muslim population, was insufficient; there were many epidemics of infectious diseases, and the mortality rate was high. On January 1, 1892, Bayerová assumed her duties in Tuzla (21). According to her own official report, between January and March she treated 118 female patients, of whom 47 were Muslim, and visited 213 Muslim women of the district in their homes (23). While she wrote in private letters to her friends that she was delighted with her work with 'those uneducated and friendly women' (12), she was continuously involved in conflicts with her superiors from the very beginning of her service. She complained, with good reason, about the disorganization surrounding her ad hoc created office and her low remuneration. The Austro-Hungarian army had supplied her with neither accommodation nor an office. Bayerová was forced to organise both facilities, for which her salary proved to be insufficient. The question of whether she was expected to charge patients a fee remained unresolved, and when she decided to treat poor women cost free, she personally had to pay for their medication (21). According to Nečas, she sought continuously to practise her own concept of a female physician's duty, to treat and help 'all women', while her superiors urged her to restrict her caregiving to Muslim women. She was also required to visit the district's Muslim villages on horseback, though she had never learned to ride (21).

Bayerová considered her work thwarted by the Austro-Hungarian army and sought the intervention of Kállay, who was ready to support her claims and ideas. At Bayerovás instigation, the Minister created the role of 'female health officer' (Amtsärztin) at a fixed, adjusted remuneration. He also decreed that an Austro-Hungarian female health officer was entitled to treat patients regardless of their religion, nationality or gender (21). 
However, Bayerová had alienated herself from her Austro-Hungarian surroundings to the point that, after three months, she requested a transfer to 'higher located' Sarajevo on account of her poor health. During her short residence in Tuzla she had caught an infection with diphtheria and come down with influenza twice (12). Not least due the fact that her mother and her brother had died young of "emaciation" she suffered from an excessive fear to contract tuberculosis which instigated her to avoid low situated "unhealthy" settings throughout her life (23). The transfer was authorized in August 1892. She expected to function as a female health officer in Sarajevo, but soon complained in letters to her friends that her superiors used her for paperwork (21).

In Sarajevo, Bayerová moved in with Adelina Paulina Irby (1831-1912) and Priscilla Johnston (25), who had established a girls' secondary school in Sarajevo in 1871 (which the Austro-Hungarian authorities reluctantly tolerated because of the ladies' reputation as enthusiastic supporters of Serb nationalism). ${ }^{2}$ Against this background, the Austro-Hungarian authorities treated her as an unwanted person who had to quit her service, as she expressed in a letter to Krásnohorská. Her father's death in the late autumn of 1892 provided her with a strong argument to leave the country, despite Kállay's appeals that she continued her work and 'help the villages' (21).

${ }^{2}$ For the earlier cooperation of Czech feminists with Irby's project during the 'Herzegovina uprising' in Bosnia (1875-1877), see Anderson D. Two Women Travellers in the Balkans in the 1860s: Georgina Muir Mackenzie, Adeline Paulina Irby. Proceedings of the BRLSI. Bath Roval Literay and Scientific Institution) 8 (2004); http://www.brlsi.org/proceed04/lunch200311. htm (accessed on October 3, 2008); see also McVicker MF. Georgina Mary Muir Mackenzie (Lady Sebright, ?-1874, and Adeline Paulina Irby, 1831-1911, p. 105108. In: McVicker MF. Women Adventurers, 17501900. A Biographical Dictionary, with Excerpts from Selected Travel Writings. Jefferson, London: McFarland and Company Inc., Publishers; 2008; p. 107.
Several Czech studies have explored why Bayerová did not pursue her mission in $\mathrm{BH}$ $(13,21,23)$. Anna Honzaková (13), the third female Czech physician, invokes Bayerovás fear that her health was seriously at risk after she had contracted several infectious diseases in Tuzla. The Czech historian Ctibor Nečas (21) points to the inevitable national and political antagonism between a radical Czech feminist and the Austro-Hungarian authorities in $\mathrm{BH}$, while her most recent biographer Marie Bahenská (21) depicts Bayerová as an irresolute personality who, despite her political radicalism, might have preferred a quiet middle-class life in more comfortable and lofty located 'healthy' settings to the fulfilment of her 'historical mission.

In 1893, Bayerová returned to Prague to dedicate herself to a campaign for Austrian 'women's need of female physicians', which was eventually supported by the Austrian 'German' Social Democracy. Bayerovás Bosnia experience inspired the slogan that 'not just religious, but also natural modesty' should be considered sufficient justification for accrediting female physicians in Austria $(26,10)$.

Later in 1893, Bayerová returned to Switzerland, where she worked as a medical educator in girls' schools in Berne. In 1900 , financial problems compelled her to work again as a physician in a sanatorium near Geneva (22). Since women's admission to Austrian medical schools in 1897, Krásnohorská had repeatedly urged Bayerová to have her degree recognised in Austria and to practise in Prague. But in 1900, Bayerová finally refused, and her mentor parted ways with her $(23,27)$

In 1910, Bayerová returned to Prague and took up employment as a school physician. However, the low remuneration compelled her to request Austrian recognition of her degree in 1913. She worked at a mental hospital in Bohnice, near Prague, until 1916. 
Bayerová died in 1924 at the home of her friend Libuše Bráfová, with whom she lived upon her return to the Czech lands. Her burial was attended by thousands of compatriots who wished to honour the popular 'Czech heroine'.

\section{Bayerová's Publishing Activities}

Bayerová restricted her research activities to her thesis on the blood counts of infants and new-borns, which was quoted repeatedly in the Journal of Czech Physicians (28). From the early 1880s, she predominantly wrote popular scientific articles in Ženské Listy, most of which concerned women's health issues, hygiene and hygiene education. She was also the author of a popular Swiss booklet against alcoholism and its negative consequences in form of male domestic violence against women and children which had been edited by the Swiss temperance movement since 1897 (9). In 1907, she edited and published Anna Fischer-Dückelmann's popular medical book Die Frau als Hausärztin (German, 1901, Women as Family Doctors) under the title Žena lékařkou in Czech translation (29). As the title indicates, the book elucidated the human anatomy, pregnancy, the necessity of healthy nutrition, attire and sports, childhood illnesses, modern education, domestic remedies, medicinal herbs and female sexuality for common women. The book's liberal, feministmaternalist character is evident in its provision of a chapter on contraception, which recommended the diaphragm (pessar) as a new contraceptive method under female control (30).

\section{Concluding Remarks}

As a symbol of the Czech women's movement, Anna Bayerová was expected to pioneer women's education and medicine by scrupulously performing the duties of an
Austro-Hungarian female health officer in BH. While the 1891 introduction of the office was based officially on the presence of a female Muslim population, Bayerová obviously was not ready to accept such restrictions. Though she succeeded in redefining her role, she left the country after one year, due in large part to the fact that her gender and her liberal attitudes made her an outsider.

Authors' Contributions: Conception and design: HT and BF; Acquisition, analysis and interpretation of data: BF and HT; Drafting the article: BF and HT; Revising it critically for important intellectual content: HT and BF; Approved final version of the manuscript: $\mathrm{BF}$ and $\mathrm{HT}$.

Conflict of Interest: The authors declare that they have no conflict of interest.

\section{References}

1. Honzáková A. MD Anna Bayerová 1853-1924: The first Czech female doctor in Switzerland [in Czech]. Praha: Ženská národní rada; 1937.

2. Matoušek O. Anna Bayerová, the first Czech female physician [in Czech]. In: Matoušek $O$, editor. Lékaři a prŕrodovědci doby Purkyňovy. Životopisné studie. Praha: Státní zdravotnické nakladatelství; 1954. p. 233-44.

3. Bahenská M. Dr. Anna Bayerová, MD: ‘... striving against the stream ...' [in Czech]. In: Felcman O, Macek Z, editors. Mezi Hradcem Králové a Plzní: Východočech na českých univerzitách: sborník in memoriam prof. PhDr. Zdeňku Mackovi. Ústí nad Orlicí: Oftis; 2006. p. 17-23.

4. Tomáš V. Dr. Anna Bayerová, MD (1853-1924). The first Czech female physician in Switzerland [in German]. In: Blaser R, Buess H, editors. Internationaler Kongress für Geschichte der Medizin. 19. Kongress, Basel, September 1964: Verhandlungen. Aktuelle Probleme aus der Geschichte der Medizin. Basel: Karger; 1966. p. 467-9.

5. Navrátil M, editor. Enzyclopaedia of Czech physicians. 1000 short Biographies: Memory of the 50th Anniversary of the Association and Journal of Czech Physicians [in Czech]. Praha: Nakl. Spisovatelovym; 1913. p. 14.

6. Brinkschulte E. Selected Biographies of the Berlin documentation: German female physicians in the Empire [in German]. In: Brinkschulte E. Institut 
für Geschichte der Medizin der Freien Universität Berlin, editors. Weibliche Ärzte. Die Durchsetzung des Berufsbildes in Deutschland. Berlin: Edition Hentrich; 1993. p. 169-89.

7. Klimpel V. Women in Medicine. Historico-biographical encyclopaedia from the beginnings to the twentieth century [in German]. Hürtgenwald: Guido Pressler Verlag; 2001. p. 39.

8. Windsor LL. editor. Women in Medicine. An Enzyclopedia. Santa Barbara, CA: ABC-CLIO; 2002. p. 27.

9. Bayer A. We women and alcoholism. According to a lecture given in Berne [in German]. Basel: Schriftstelle des Alkoholgegnerbundes; 1897; Reinhardt; 1902.

10. Fuchs B. Women's need of female physicians: A feminist campaign between Vienna, Prague and Sarajevo [in German]. In: Tutavac V, Korotin I, editors. Frauenbildung und Emanzipation in der Habsburgermonarchie. Vienna: praesens-Verlag; 2016. p. 94-127.

11. Bayerová A. Girls' Hygiene. Lecture by Dr. A. Bayerová, MD [in Czech]. Ženské Listy. 1883;(XI):1820.

12. Note 'Czech Female Doctor [in Czech]. Časopis lékařů českých. 1891;(49):1013.

13. Honzaková A. The activities of Dr. Anna Bayerová, MD in Bosnia [in Czech]. In: Honzáková A, editor. Československé studentky let 1890-1930. Almanach na oslavu ctyřicátého výroči založení ženského studia Eliškou Krásnohorskou. Praha: Ženská Národni Rada a Spolek Minerva; 1930. p. 51-5.

14. Burton A. Contesting the Zenana. The Mission to Make 'Lady Doctors for India', 1874-1885. Journal of British Studies. 1996;(35):368-97.

15. Fuchs B. Orientalising Disease. Austro-Hungarian Policies of 'Race', Gender, And Hygiene in Bosnia and Herzegovina, 1878-1914. In: Trubeta S, Turda M, Promitzer C, editors. Health, Hygiene and Eugenics in Southeastern Europe until 1945. Budapest: CEU Press; 2011. p. 57-85.

16. Helczmanowszki H. Austria-Hungary's population [in German]. In: Geschichte und Ergebnisse der zentralen amtlichen Statistik in Österreich 1829-1979, edited by Österreichisches Statistisches Zentralamt. Vienna: Österreichische Staatsdruckerei; 1979. p. 369-402.

17. Public Health in Bosnia and Herzegovina 18781901 [in German], edited by Landesregierung für Bosnien und die Hercegovina. Sarajevo: Landesdruckerei; 1903. p. 17.

18. Ibrahimagić OC, Ibrahimagić A, Smajlović D, Sinanović O. Physicians in Tuzla area in nine- teenth century [in Bosnian]. Med Arh. 2006;60(6 Suppl 2):117-20.

19. Ibrahimagić OC, Zukić S, Čustović A. Health Care in Tuzla and Tuzla Area in the Second Half of the Nineteenth Century. Acta Med Sal. 2009;38(1):15.

20. Necas C. Activities of the official female doctors in Bosnia and Herzegovina 1892-1918 [in Bosnian]. Istorijski zbornik Instituta za istoriju u Banjaluci. 1988;(9):91-110.

21. Nečas C. The First Female Health Officer in Bosnia [in Czech]. Časopis Matice Moravské. 1983;(102):245-57.

22. Nečas C. Among Muslim Women. The Female Health Officers in Bosnia and Herzegovina 1892 1918 [in Czech]. Brno: Masaryk-University; 1992.

23. Bahenská M. Woman in Medicine: Anna Bayerová [in Czech]. In: Vošahlíková P, Martínek J, editors. Cesty $\mathrm{k}$ samostatnosti. Portréty žen v éře modernizace. Praha: Historický ústav; 2010. p. 7290.

24. Ziegeler B. Female Physicians and Public Health Insurance Companies: female medical professionals in Berlin, 1893-1935 [in German]. Weinheim: Deutscher Studienverlag; 1993.

25. Hadžiselimović O. Two Victorian Ladies and Bosnian Realities, 1862-1875: G.H. MacKenzie and A.P. Irby. In: Allcock JB, Young A, editors. Black Lambs and Grey Falcons. Women Travellers in the Balkans. New York: Berghahn Books; 2000. p. 1-8.

26. Gamper M. Die Ärztin gehört für die Frau. Registered female physicians and female physicians in social services in Vienna, 1900-1938 [in German; MA-Thesis]. Vienna: University of Vienna; 2001.

27. Krásnokorská E. In memory of the second Czech female physician [in Czech]. In: Honzáková A, editor. Československé studentky let 1890-1930. Almanach na oslavu ctyřicátého výroči založení ženského studia Eliškou Krásnohorskou. Praha: Ženská Národni Rada a Spolek Minerva; 1930. p. 45-50.

28. Bayer A L. On the numerical proportion of the red and white blood cells in the blood of newborn and infants [in German]. Bern: Jent \& Reinert; 1881.

29. Fischer-Dückelmann A (author), Bayerová A (editor). The Female Doctor: a medical book dedicated to health care and the treatment of diseases with special regard to female disorders and childhood illnesses, midwifery and child care [in Czech]. Vídeň: Jul. Müller; 1907.

30. Meyer P. Physiatry and German maternal feminism: Dr. Anna Fischer-Dückelmann critiques academic medicine. Can Bull Med Hist. 2006;23(1):145-82. 